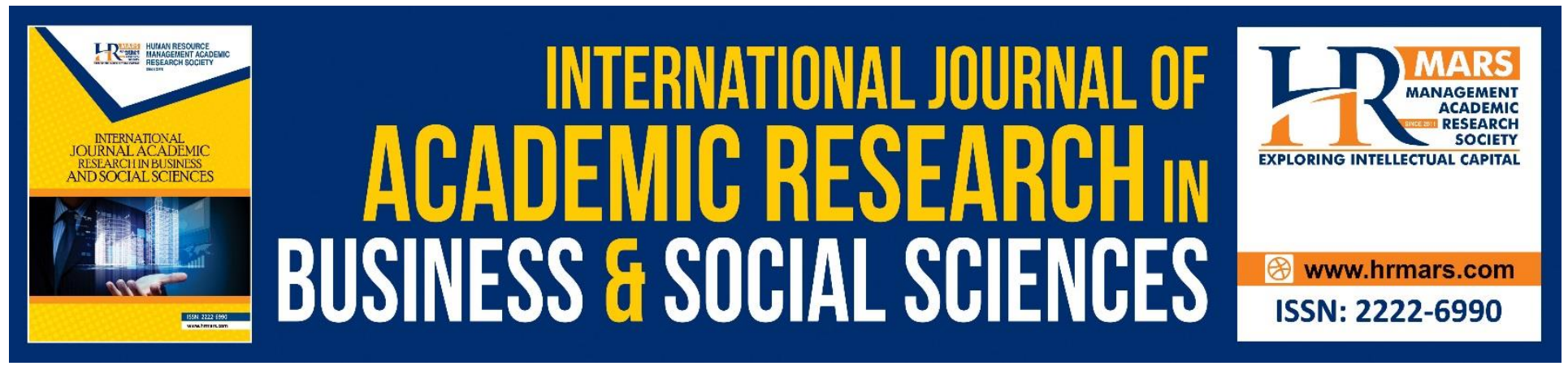

\title{
An Investigation of Corporate Governance Mechanisms on Real Earnings Management toward the Changes on Firm Performance: Evidence from Jordan
}

Muhammad Dakhlallh, Norfadzilah Rashid, Ahmad Syukri Yazid, Fauzilah Salleh, Asyraf Afthanorhan, Puspa Liza Ghazali, Wan Norhayate Wan Daud, Fakrul Anuar Zainol

To Link this Article: http://dx.doi.org/10.6007/IJARBSS/v8-i11/5198 DOI: 10.6007/IJARBSS/v8-i11/5198

Received: 11 Oct 2018, Revised: 30 Nov 2018, Accepted: 03 Dec 2018

Published Online: 11 Dec 2018

In-Text Citation: (Dakhlallh et al., 2018)

To Cite this Article: Dakhlallh, M., Rashid, N., Yazid, A. S., Salleh, F., Afthanorhan, A., Ghazali, P. L., ... Zainol, F. A. (2018). An Investigation of Corporate Governance Mechanisms on Real Earnings Management toward the Changes on Firm Performance: Evidence from Jordan. International Journal of Academic Research in Business and Social Sciences, 8(11), 1389-1400.

Copyright: (C) 2018 The Author(s)

Published by Human Resource Management Academic Research Society (www.hrmars.com)

This article is published under the Creative Commons Attribution (CC BY 4.0) license. Anyone may reproduce, distribute, translate and create derivative works of this article (for both commercial and non-commercial purposes), subject to full attribution to the original publication and authors. The full terms of this license may be seen at: http://creativecommons.org/licences/by/4.0/legalcode

Vol. 8, No. 11, 2018, Pg. 1389 - 1400

http://hrmars.com/index.php/pages/detail/IJARBSS

JOURNAL HOMEPAGE

Full Terms \& Conditions of access and use can be found at http://hrmars.com/index.php/pages/detail/publication-ethics 


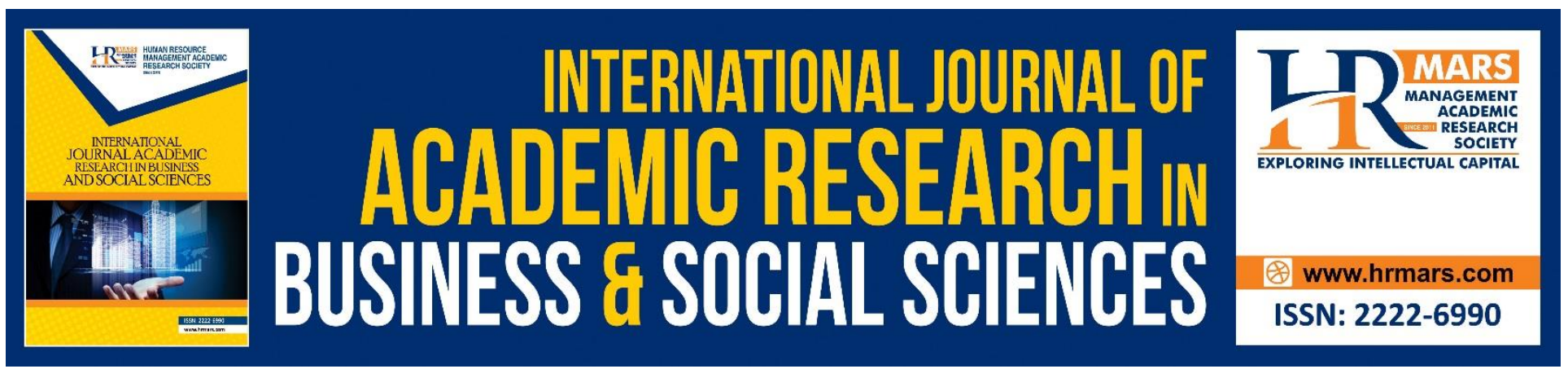

\title{
An Investigation of Corporate Governance Mechanisms on Real Earnings Management toward the Changes on Firm Performance: Evidence from Jordan
}

\author{
${ }^{1}$ Muhammad Dakhlallh, ${ }^{2}$ Norfadzilah Rashid, ${ }^{3}$ Ahmad Syukri Yazid, \\ ${ }^{4}$ Fauzilah Salleh, ${ }^{5}$ Asyraf Afthanorhan, ${ }^{6}$ Puspa Liza Ghazali, ${ }^{7}$ Wan \\ Norhayate Wan Daud, ${ }^{7}$ Fakrul Anuar Zainol \\ 1,2,3,4,5Faculty Economics \& Management Science, Universiti Sultan Zainal Abidin, Malaysia \\ Corresponding Author: nikmfadzilah@unisza.edu.my
}

\begin{abstract}
Corporate Governance were always considered as protection tool towards the stakeholders interest in the capital market. However, the manipulation of the Real Earnings Management activities were also create a major treat among of the stakeholders whenever it were engaged among of top management of the business organizations. In this particular study, it was discussed with the few components under corporate governance mechanism together with theirs impacts on the firm performance in the business organization. It was believed as the selected components were have a significant influence towards the changes of the value relevance towards the business organizations in the capital market activities.
\end{abstract}

\section{Introduction}

In recent times, Corporate Governance has been enlisted as top priority for the economic growth of any country (Bansal and Sharma, 2016). So, most countries across the globe introduced new codes of better governance practices to align managers interest with the wealth maximization objective of the shareholders. But, despite the introduction of the codes of best governance practices in Jordan in 2009, the results that it has achieved can be said to be minimal as there are, where the Jordanian companies have not yet reached the phase of full compliance with the corporate governance code (Abbadi, Hijazi, and Al-Rahahleh, 2016).

literature studies show have devoted considerable attention to the impact of corporate governance mechanisms on corporate behavior. while shows that these mechanisms have a substantial impact on earnings management, and affect performance. In this paper the researcher 
INTERNATIONAL JOURNAL OF ACADEMIC RESEARCH IN BUSINESS AND SOCIAL SCIENCES

Vol. 8, No. 11, Nov, 2018, E-ISSN: 2222-6990 @ 2018 HRMARS

an examines how governance mechanisms influence firm performance when measured performance is adjusted for the impact of real earnings management.

\section{Background of the Study}

The basic purpose of financial reports is to provide an insight for the different stakeholders and potential investors about the financial performance of the business. The main concern is about the presence of Earnings Management practices in financial reporting processes that produce manipulated and is leading financial reports in order to influence investor and stakeholder decisions (Kumari, Kumari, Pattanayak, and Pattanayak, 2017).

In recent years and after the collapse of many companies, became the study of corporate governance in developing countries is very important issue (Arora, Arora, Sharma, and Sharma, 2016). So, Corporate Governance is a structure that monitors the behavior of managers, so that they can be applied by the board of directors and investors, and can affect aspects of management including the management of earnings and structure of capital (Yaseen and Al - Amarneh, 2015). As indicated previous studies have also suggested that the administration may use Earnings Management to increase income to hide its poor performance (Habib, Uddin Bhuiyan, and Islam, 2013). So, the relationship of Earnings Management with firm performance is variable, depending on the quality of the firm's management (Tang and Chang, 2015).

The main aim of this study is to investigation of the effect of corporate governance mechanisms (board of directors, ownership structure and audit committee) on firm performance when measured performance is adjusted for the impact of real earnings management in developing country such as Jordan.

\section{Literature Review}

Corporate Governance

There are various theorists and writers from the renowned countries who have tried to define the term "the combine meaning". Cadbury Report (1992), suggests the responsibilities as well as duties of the board of governors in an organization and contends that a clear outline of this by Corporate Governance definitely takes the organization to the pinnacle of the success. There are some other definitions which stated that Corporate Governance is a legal framework, and it this framework deals with the rules, regulations, procedures and the conduct of the private sector (Yasser, Entebang, and Mansor, 2015). According to Buallay, Hamdan, and Zureigat (2017). "Corporate Governance is a combination of policies, laws and instructions influencing the way a firm is managed and controlled, it consists of a framework of rules to grant transparency and fairness in the relationship between the firms and its shareholders. In Jordan, Securities Depository Center issued in September 2009 a Corporate Governance guide that defines Corporate Governance as "is the system by which organizations are directed and controlled". (SDC, 2009).

\section{Firm Performance}

According to Lebas (1995) "performance is the transference of the complex reality of performance in organized symbols that can be related and relayed under the same circumstances". Financial statement of a company is an indicator of the performance of the company. So, If 
performance of a company is good, as a result the company will strengthen its management for the disclosure of the quality (Herly, 2011).

Broadly speaking, the firm's success is reflected through its performance. Thus measuring the performance is critical for a firm's effective management (Demirbag, Tatoglu, Tekinkus, and Zaim, 2006). A system can never be improved if its outcomes are not measured. So it can be stated that to improve the performance of an organization these measurements are necessary because they help in determining the impact of the resources of the organization. Through the determination of such measurements, a firm is enabled to compare its performance in various instances (Sharma and Gadenne, 2002).

\section{Corporate Governance Mechanisms and Firm Performance}

Corporate governance variables have been shown in other contexts to affect firm performance and behavior. Such variables include board independence, CEO duality, managerial ownership, family ownership, government ownership, Institutional ownership in the firm, audit committee independence, and audit committee Financial expertise. In this section we discuss these variables, which will be the focus of our empirical analysis.

Board of Directors and Firm Performance

There is an ongoing debate in the area of Corporate Governance to examine its influence on overall corporate performance by different business in the world. The independent board of directors plays an important role in monitoring the firm's management team. Therefore, the extent to which the board is independent may attract investors (Muniandy and Hillier, 2015). Muniandy and Hillier (2015) report that board independence has a positive influence on firm performance in South Africa. On the other hand, Detthamrong, Chancharat \& Vithessonthi (2017) they find that for an average firm, Corporate Governance board independence has no effect on performance.

CEO duality arises when the chairman of the board also occupies the CEO position. Advocates of CEO duality cite the argument that duality results in maximized effectiveness, which will be represented in the company performance improvement (Peng, Zhang, \& Li, 2007). Additionally, Haniffa and Hudaib (2006) reported that firms with separate CEO and chairman of the board appeared to report superior performance compared to those with duality of role. Sharma and Sharma (2016). Found insignificant relationship between CEO duality and firm performance. Detthamrong, Chancharat \& Vithessonthi (2017). They found that for an average firm CEO duality has no effect on performance.

Ownership Structure and Firm Performance

The researches that have been conducted in the past to check the effects of management impartiality of ownership show the results that are conflicting. A study that was conducted by Kim, Kitsabunnarat, and Nofsinger, in the year 2004, showed the results in which there was a negative relationship between performance of the firm and the managerial ownership. On the other hand, in the past few years some researches show that the relationship between the management equity ownership and firm's value and agency is a positive relation (Iskandar, Rahmat, Noor, and Saleh, 2011). But there exists empirical evidence that the correlation between the ownership of the managers and the performance of the firm and the value of the market are mixed (Ghazali, 2010). 
An explanation based on the agency theory is that family dominance in family-based companies is assumed to be associated with lower extents of board independence, higher agency cost and lower level of corporate transparency, and furthermore, the increase of family influence would lower the probability of shareholders taking disciplinary actions (Ballesta \& Garcia-Meca, 2005). According to Al-Ghamdi and Rhodes, (2015) who conducted research on the Family Ownership, Corporate Governance and Performance in the firms enlisted in Saudia. The findings from that research reveal that there exists no relation between ownership and the firm performance. While Khamis, Hamdan, and Elali, (2015) concluded the absence of significant relationship of performance with family ownership.

The association between Goverment ownership and firm performance has motivated many empirical studies. Porta, Lopez-de-Silanes, Shleifer, and Vishn, (1999) argue that the incentive for government to own shares in firm might be related to achieving political objectives rather than economic objectives. However, the empirical evidence for the relationship between firm performance and state ownership has been mixed results. Some studies report a positive effect of government ownership on firm performance (Liao and Young 2012), while other studies present a negative effect (Mahmood et al. 2011). And study Darko, Darko, Aribi, Aribi, Uzonwanne, and Uzonwanne, (2016) show to no relationship between government ownership and firm performance.

Institutional ownership is important determinant of firm performance. For instance, Agyemang and Castellini (2015) focused on how ownership control and board control systems operate in corporate firms in an emergent economy, assuming that these systems are essential for enhancing good Corporate Governance practices in emerging countries. Mashayekhi and Bazaz (2008) investigated the role played by Corporate Governance on the performance of a firm and found the absence of positive correlation between the existence of institutional investors and the performance of a firm. Arora et al., (2016) found the presence of significant as well as negative correlation between the performance of a firm and the institutional ownership.

Audit Committee and Firm Performance

Audit committee independence is considered one of the fundamental monitoring tools. Usually, board of directors, their representatives, or other principals delegate authority and responsibility to the audit committee to use financial reports to assess the performance of management. This trend is in line with agency theory (Jensen and Meckling, 1976). According to the observations recorded by Hamdan, Sarea and Reyad (2013), the performance of the firm is significantly influenced by the independence of audit committee. In another research study, Ghabayen (2012) has investigated the relation of the audit committee composition with firm performance in year 2011 . The findings of the study show that there is no relation between audit committee composition and firm performance.

It is very obvious that it becomes very important for audit committee members to contain the people who are competent and have an experience related to financial aspects (Rashidah \& Fairuzana, 2006). DeZoort and Salterio (2001) are of the view that an audit committee that comprises the experts helps in achieving better financial performance. Studies conducted recently confirm that accounting expertise, within the board (which is characterized by strong governance) adds to a greater degree of efficiency in audit committee monitoring, and results in improved conservatism (Krishnan \& Visvanathan, 2009). 
INTERNATIONAL JOURNAL OF ACADEMIC RESEARCH IN BUSINESS AND SOCIAL SCIENCES

Vol. 8, No. 11, Nov, 2018, E-ISSN: 2222-6990 @ 2018 HRMARS

\section{Real Earnings Management}

Earnings Management is very important for company in preparing the financial statement and it has been used by company insiders to manipulate and provide the financial information to outsiders in order to secure their positions and interest (Lin, Riccardi, and Wang, 2012).

The recent literature reveals that listed firms may also use real earnings management. Such real activities manipulation departs from normal operational practices and occurs when managers alter the timing or structure of transactions, investments, and resource allocations to boost accounting earnings in the current period (Roychowdhury, 2006). Graham, Harvey, and Rajgopal (2005) provide survey evidence to show that managers prefer real earnings management, even though it may reduce firm value and increase related costs.

\section{Corporate Governance Mechanisms and Real Earnings Management}

Recently, the increased number of bankruptcies that are caused by the frauds in the financial accounting resulted as the increase of focus on the Corporate Governance, which became a major reason behind the implementations of various practices in the accounting (loana, 2014). Another issue that has come in front is the failure regarding the behaviors that are unethical and which affect the Earnings Management (Uadiale, 2012).

Board of Directors and Real Earnings Management

Several studies display relationship between the board independence from management and the board supervision efficiency. Baccouche and Omri (2014) assess the effect of multiple relationships between boards" independence and Earnings Management for the French listed firms. It appears that board dominated by outside directors may increase the level of Earnings Management, which implies positive relationship. Kang and Kim (2012) indicated that board independence constrain Real Earnings Management practices. Hashemi and Rabiee (2011) document that higher proportion of independent directors and board help in restraining Real Earnings Management.

The CEO duality is highly considered when assessing the quality of earnings reported, since the two posts of CEO and chairman played a significant role in minimizing the possibility of accounting enforcement by SEC for alleged violation of GAAP (Cadbury, 1992). Jouber and Falehfakh (2014) assess whether there is a link between CEO duality and Earnings Management. The result indicates that chairman's duality is positively and significantly associated with Earnings Management. Specifically, Visvanathan (2008) found a negative association between CEO duality and abnormal cash flow from operation and discretionary expenses, but the relation is not significant.

Ownership Structure and Real Earnings Management

The interest of the managers in any firm is approximately synchronized once the ownership of the mangers reaches the optimal possibility. Thus it can be said that the equity of the firm is directly held in the hands of the managers. Therefore, as management ownership increases, the incentives to manipulate earnings will decrease (Cheng and Warfield, 2005). Laux and Laux (2009) are of the view that high managerial ownership is an effective governance device and it helps in reducing Earnings Management.

The reputation and the long term orientations means that the family firms are those who do not think in an opportunistically in reporting their earning statements Ali, Chen, and Radhakrishnan (2007). In a conclusive way it could be stated that as compared to the non-family firms, family firms 
are more suitable for maximizing the wealth of a firm in the long term (Bona, Perez, and Santana, 2008). Study by Ghazali and Weetman (2006) reported a significant negative association between the proportion of family members and Earnings Management.

The extremely concerted state-ownership is the determining factor in the character of the agency issue as it is the conflict of interests between the shareholders in control and shareholders in minority (chen \& zhang, 2014). Lo, Wong, and Firth (2010b) found that if the listed firm's is controlled by government, Earnings Management will decrease with the increase ratio of state ownership. While Shan (2013) found the government ownership has positive correlation with the concept of Earnings Management.

The bulk of literature from previous researches has explained that sophisticated investors are typically defined in terms of institutional investors and perform the role of monitoring effectively in order to reduce pressures for management. Charitou, Lambertides, and Trigeorgis (2007), they found management of firms with institutional ownership have greater tendency to manage earnings downwards.

Audit Committee and Real Earnings Management

The independence of audit committee allowed the audit committee members to be effective in carrying out their oversight functions. Prior studies by Abbott, Parker, and Peters (2004) have identified a negative relationship between audit committee independence and earnings restatement. Visvanathan (2008) found that audit committee independence is insignificant in constraining Real Earnings Management. Rahman and Ali (2006) revealed that there is no significant relationship between independence of audit committee and the incidence of Earnings Management.

The members of audit committee are not only independent but also have the expertise to be in the committee (Sahlan, 2011). Badolato, Donelson, and Ege (2014) argued that audit committee with financial expertise and high relative status is more effective at deterring Earnings Management. While Velte and Stiglbauer (2011) found result shows a significant negative relationship between the independent audit committee expertise and Earnings Management.

3.6 Real Earnings Management and firm performance

the found that Earnings Management practices are performed to meet analysts and stakeholders' expectations about a firms' financial performance (Kumari, Kumari, Pattanayak, and Pattanayak, 2017). Fayoumi, Abuzayed, and Alexander (2010) states that a direct relationship between Earnings Management and firm performance also exists. Furthermore, in 2012 Ardekani, Younesi, and Hashemijoo, identified that there is a significant negative relationship between the magnitude of Earnings Management and the measures of firm performance.

\section{Research Framework}

The framework shown in Figure 1 below explains association among the independent variables, mediator variable and dependent variable. This study will examine the impact of the board of directors mechanisms (board independence, CEO duality), ownership structure mechanisms (managerial ownership, family ownership, government ownership and institutional ownership), and audit committee mechanisms (audit committee independence, audit committee financial expertise) on real earnings management and firm performance. 
INTERNATIONAL JOURNAL OF ACADEMIC RESEARCH IN BUSINESS AND SOCIAL SCIENCES

Vol. 8, No. 11, Nov, 2018, E-ISSN: 2222-6990 @ 2018 HRMARS

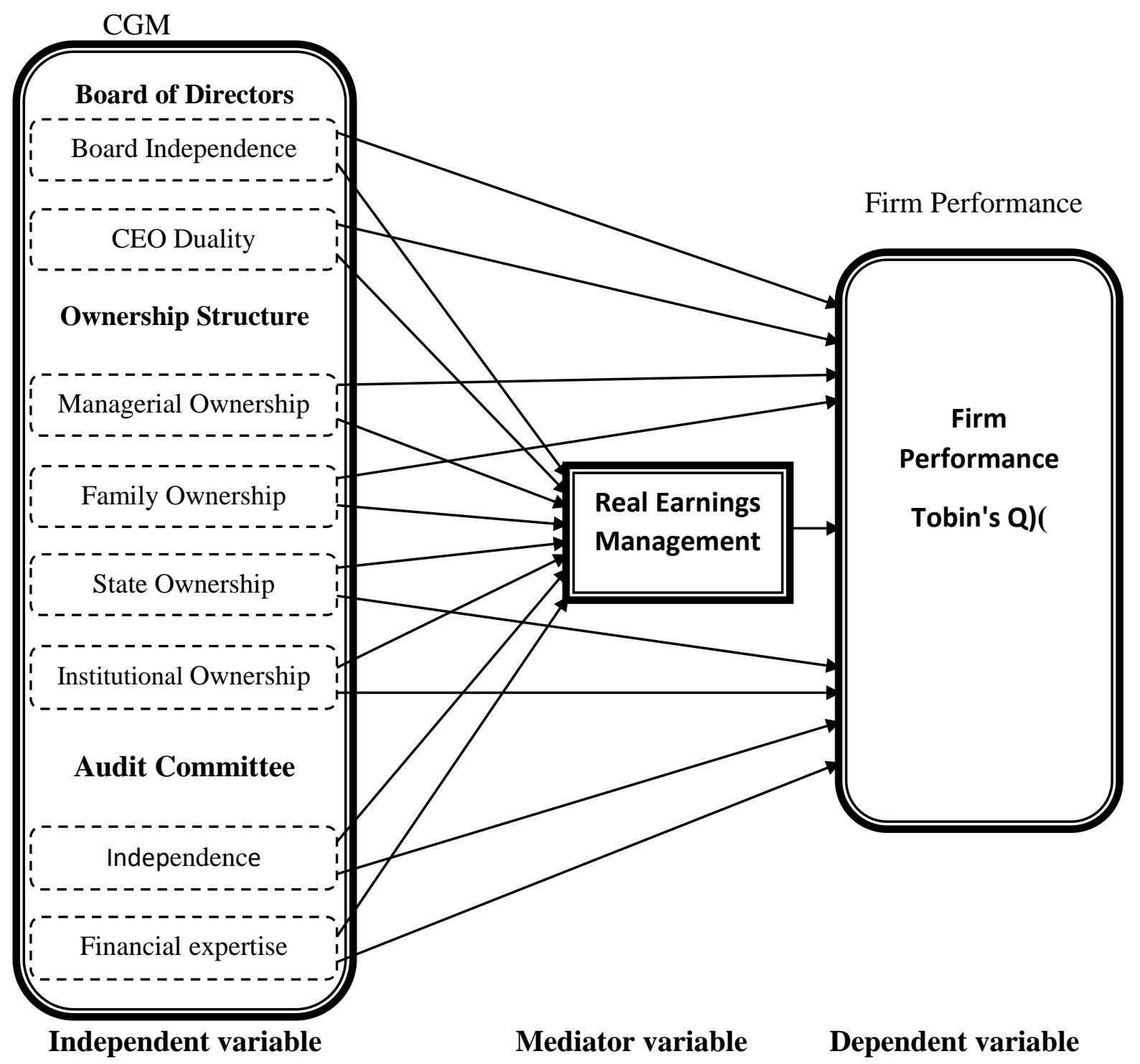

Figure 1 Research Framework

The various studies undertaken on corporate governance, earnings management and firm performance are mostly concentrated on the corporations based in the U.S., the U.K. and other developed countries. It necessitates the need for more studies to be undertaken in developing countries identifying the association among corporate governance, earnings management and firm performance. So, this study investigate whether corporate governance mechanisms affects the relationship between real earnings management and firm performance in developing country such as Jordan. When comparing these results on a gross basis, these months are closely related to each other. The corporate governance mechanisms results in transparency and reliability of firm financial information and enhance investor believe and positively influences the overall firm's performance. Similarly on a wider ground the various attributes of corporate governance mechanisms (board of 
INTERNATIONAL JOURNAL OF ACADEMIC RESEARCH IN BUSINESS AND SOCIAL SCIENCES

Vol. 8, No. 11, Nov, 2018, E-ISSN: 2222-6990 @ 2018 HRMARS

directors, ownership structure, audit committee) work as a constraint for real earnings management practices and limits the scope of real earnings manipulation.

\section{References}

Abbadi, S. S., Hijazi, Q. F., \& Al-Rahahleh, A. S. (2016). Corporate governance quality and earnings management: Evidence from Jordan. Australasian Accounting Business \& Finance Journal, 10(2), 54.

Abbott, L. J., Parker, S., \& Peters, G. F. (2004). Audit committee characteristics and restatements. Auditing: A Journal of Practice \& Theory, 23(1), 69-87.

Agyemang, O.S. and Castellini, M. (2015),"Corporate Governance in an emergent economy: A case of Ghana", Corporate Governance: The international journal of business in society, 15(1), 52-84.

Al-Ghamdi, M., \& Rhodes, M. (2015). Family Ownership, Corporate Governance and Performance: Evidence from Saudi Arabia. International Journal of Economics and Finance, 7(2), 78-89.

Ali, A., Chen, T., \& Radhakrishnan, S. (2007). Corporate disclosures by family firms. Journal of Accounting and Economics, 44, 238-286.

Arora, A., Arora, A., Sharma, C., \& Sharma, C. (2016). Corporate Governance and firm performance in developing countries: evidence from India. Corporate Governance, 16(2), 420-436.

Baccouche, S., \& Omri, A. (2014). Multiple Directorships of Board Members and Earnings Management: Empirical Evidence from French Listed Companies. Journal of Economic and Financial Modeling, 2(1), 13-23.

Badolato, P. G., Donelson, D. C., \& Ege, M. (2014). Audit committee financial expertise and Earnings Management: The role of status. Journal of Accounting and Economics, 58(2), 208-230.

Ballesta, J. P. S., \& Garcia-Meca, E. (2005). Audit qualifications and Corporate Governance in Spanish listed firms. Managerial Auditing Journal, 20(7), 725-738.

Bansal, N., \& Sharma, A. K. (2016). Audit committee, Corporate Governance and firm performance: empirical evidence from India. International Journal of Economics and Finance, 8(3), 103.

Bona, C., Perez, J., \& Santana, D. (2008). Family control and Earnings Management. Spanish Accounting Review, 10(1), 11-34.

Buallay, A., Hamdan, A., \& Zureigat, Q. (2017). Corporate Governance and Firm Performance: Evidence from Saudi Arabia. Australasian Accounting Business \& Finance Journal, 11(1), 78.

Cadbury, A. 1992. The Committee on the Financial Aspects of Corporate Governance and Gee and Co. Ltd. Report 61.

Charitou, A., Lambertides, N., \& Trigeorgis, L. (2007). Earnings behaviour of financially distressed firms: the role of institutional ownership. Abacus, 43(3), 271-296.

Chen, J. J., \& Zhang, H. (2014). The impact of the Corporate Governance code on Earnings Management-Evidence from Chinese listed companies. European Financial Management, 20(3), 596-632.

Cheng, Q., \& Warfield, T. (2005). Equity incentives and Earnings Management. The Accounting Review, 80, 441-476.

Darko, J., Darko, J., Aribi, Z. A., Aribi, Z. A., Uzonwanne, G. C., \& Uzonwanne, G. C. (2016). Corporate Governance: the impact of director and board structure, ownership structure and corporate 
INTERNATIONAL JOURNAL OF ACADEMIC RESEARCH IN BUSINESS AND SOCIAL SCIENCES

Vol. 8, No. 11, Nov, 2018, E-ISSN: 2222-6990 @ 2018 HRMARS

control on the performance of listed companies on the Ghana stock exchange. Corporate Governance, 16(2), 259-277.

Demirbag, M., Tatoglu, E., Tekinkus, M., \& Zaim, S. (2006). An analysis of the relationship between TQM implementation and organizational performance: evidence from Turkish SMEs. Journal of manufacturing technology management, 17(6), 829-847.

Detthamrong, U., Chancharat, N., \& Vithessonthi, C. (2017). Corporate Governance, capital structure and firm performance: Evidence from Thailand. Research in International Business and Finance, 42, 689-709.

DeZoort, F.T., and Salterio, S. (2001). The Effects of Corporate Governance Experience and Financial Reporting and Audit Knowledge of Audit Committee Members' Judgments. Auditing: A Journal of Practice and Theory, Vol. 20, No. 2: pp. 31-48.

Fayoumi N.A., Abuzayed, B. and Alexander, D. (2010). Ownership structure and Earnings Management in earnings markets: the case of Jordan. Journal of finance and economic. ISSN 1450-2887, Vol. 38.

Graham, J. R., Harvey, C. R., \& Rajgopal, S. (2005). The economic implications of corporate financial reporting. Journal of accounting and economics, 40(1), 3-73.

Ghazali, N. A. M. (2010). Ownership structure, Corporate Governance and corporate performance in Malaysia. International Journal of Commerce \& Management, 20, 109-119.

Ghabayen, M. A. (2012). Board characteristics and firm performance: Case of Saudi Arabia. International Journal of Accounting and Financial Reporting, 2(2), 168-200.

Ghazali, N., \& Weetman, P. (2006). Perpetuating traditional influences: voluntary disclosure in Malaysia following the economic crisis. Journal of International Accounting, Auditing and Taxation, 15 ( 2), 226-248.

Habib, A., Uddin Bhuiyan, B., \& Islam, A. (2013). Financial distress, Earnings Management and market pricing of accruals during the global financial crisis. Managerial Finance, 39(2), 155-180.

Hamdan, AM, Sarea, A. M., \& Reyad, S. M. R. 2013, 'The impact of audit committee characteristics on the performance: Evidence from Jordan', International Management Review, vol. 9, no. 1, pp. 32-41.

Haniffa, R. \& Hudaib, M. (2006). Corporate Governance Structure and Performance of Malaysian Listed Companies. Journal of Business Finance and Accounting, 33 (7-8), 1034-1062.

Herly, M. (2011). Corporate Governance and firm Performance in Indonesia. International Journal of Governance, 1(2), 384-403.

Hashemi, S. A., \& Rabiee, H. (2011). The role of Corporate Governance in real earnings management: Evidence from Iran. Interdisciplinary Journal of Contemporary Research in Business (IJCRB), 3(6), 848-857.

Ioana, A. N. G. H. E. L. (2014). Study regarding the impact of the audit committee characteristics on company performance. Studies In Business \& Economics, 9(2).

Iskandar, T. M., Rahmat, M. M., Noor, N. M., \&Saleh, N. M. (2011). Corporate Governance and going concern problems: evidence from Malaysia. International Journal of Corporate Governance, 2(2), 119-139.

Jensen, M. C., \& Meckling, W. H. (1976). Theory of the firm: Managerial behavior, agency costs and ownership structure. Journal of financial economics, 3(4), 305-360. 
INTERNATIONAL JOURNAL OF ACADEMIC RESEARCH IN BUSINESS AND SOCIAL SCIENCES Vol. 8, No. 11, Nov, 2018, E-ISSN: 2222-6990 @ 2018 HRMARS

Jouber, H., \&Fakhfakh, H. (2014). The Association Between CEO Incentive rewards and Earnings Management: Do Institutional Features matter? EuroMed Journal of Business, 9(1), 18-36.

JSC, Jordanian Securities Commission. (2009). Corporate Governance code for shareholding companies listed on Amman Stock Exchange. 1-16. Retrieved from: http://www.sdc.com.jo/arabic/images/stories/pdf/corporate_governance_companies.pdf.

Kang, S. A., \& Kim, Y. S. (2012). Effect of Corporate Governance on real activity-based Earnings Management: Evidence from korea. Journal of Business Economics and Management, 13(1), 29-52.

Khamis, R., Hamdan, A. M., \& Elali, W. (2015). The Relationship between Ownership Structure Dimensions and Corporate Performance: Evidence from Bahrain. Australasian Accounting, Business and Finance Journal, 9(4), 38-56.

Kim, K. A., Kitsabunnarat, P., \& Nofsinger, J. R. (2004). Ownership and operating performance in an emerging market: evidence from Thai IPO firms. Journal of Corporate Finance, 10(3), 355-381.

Krishnan, G., \& Visvanathan, G. (2009). Do auditors price audit committee's expertise? The case of accounting versus nonaccounting financial experts. Journal of Accounting, Auditing \& Finance, 24(1), 115-144.

Kumari, P., Kumari, P., Pattanayak, J. K., \& Pattanayak, (2017). Linking Earnings Management practices and Corporate Governance system with the firms' financial performance: A study of Indian commercial banks. Journal of Financial Crime, 24(2), 223-241.

La Porta, R., F. Lopez-de-Silanes, A. Shleifer, and R. Vishny. 1999. The quality of government. Journal of Law, Economics, and Organization 15 (1):222-279.

Laux, C., and Laux, V. (2009). Board Committees, CEO Compensation, and Earnings Management. The Accounting Review, Vol. 84, No. 3: pp. 869-891.

Lebas, M. J. (1995). Performance measurement and performance management. International journal of production economics, 41(1-3), 23-35.

Liao, J., and M. Young. 2012. The impact of residual government ownership in privatized firms: New evidence from China. Emerging Markets Review, 13 (3):338-351.

Lin, S., Riccardi, W., \& Wang, C. (2012). Does accounting quality change following a switch from US GAAP to IFRS? Evidence from Germany. Journal of Accounting and Public Policy, 31(6), 641-657.

Lo, A. W. Y., Wong, R. M. K., Firth, M., 2010b. Tax, financial reporting, and tunneling incentives for income shifting: an empirical analysis of the transfer pricing behavior of Chinese-listed companies. Journal of the American Taxation Association, 32 (2), 1-26.

Mahdavi Ardekani, A., Younesi, N. and Hashemijoo, M. (2012). Acquisition, Earnings Management and Firm's Performance: Evidence from Malaysia. Journal of Business Studies Quarterly, 4(1), pp. 91-110.

Mashayekhi, B., \&Bazaz, M. S. (2008). Corporate Governance and firm performance in Iran. Journal of Contemporary Accounting \&Economics, 4(2), 156-172.

Muniandy, B., Hillier, J., 2015. Board independence, investment opportunity set and performance of South African firms. Pacific-Basin Finance Journal 35, Part A, 108-124.

Peng, M. W., Zhang, S., \& Li, X. (2007). CEO duality and firm performance during china's institutional transitions. Management and Organisation Review, 3(2), 205-225. 
INTERNATIONAL JOURNAL OF ACADEMIC RESEARCH IN BUSINESS AND SOCIAL SCIENCES

Vol. 8, No. 11, Nov, 2018, E-ISSN: 2222-6990 @ 2018 HRMARS

Rashidah, A.R. \& Fairuzana Haneem, M.A. (2006). Board, audit committee, culture and Earnings Management: Malaysian evidence. Managerial Auditing Journal, Vol.21, No.7, pp.783-804.

Rahman, R. A., \& Ali, F. H. M. (2006). Board, audit committee, culture and Earnings Management: Malaysian evidence. Managerial Auditing Journal, 21(7), 783-804.

Roychowdhury, S. (2006). Earnings Management through real activities manipulation. Journal of Accounting and Economics, 42(3), 335-370.

Sahlan, L. A. (2011). The Malaysian listing requirement reforms and Earnings Management practices of public listed firms. The IUP Journal of Corporate Governance, 10(2), 7-36.

Shan, Y. G., 2013. Can internal governance mechanisms prevent asset appropriation? examination of Type I tunneling in China. Corporate Governance: An International Review 21 (3), 225-241.

Sharma, B., \& Gadenne, D. (2002). An inter-industry comparison of quality management practices and performance. Managing Service Quality: An International Journal, 12(6), 394-404.

Uadiale, O. M. (2012). Earnings Management and Corporate Governance in Nigeria. Research Journal of Finance and Accounting, 3(3), 1-10.

Velte, P., \& Stiglbauer, M. (2011). Impact of audit committees with independent financial experts on accounting quality. An empirical analysis of the German capital market. Problems and Perspectives in Management, 9(4), 17-33.

Visvanathan, G. (2008). Corporate Governance and real earnings management. Academy of Accounting and Financial Studies Journal, 12(1), 9-22.

Yasser, Q. R., Entebang, H. A., \& Mansor, S. A. (2015). Corporate Governance and firm performance in Pakistan: The case of Karachi Stock Exchange (KSE)-30. 